\title{
A COMPARISON OF THE ACTION OF MEPERIDINE AND DIAZEPAM IN ANAESTHETIC PREMEDICATION
}

\author{
A. CORMIER, M.D., F.R.C.S. (C), M. GOYETTE, M.D., \\ M. KeÉrt-SZÁntó, M.D., AND J. RHEeAuLT, M.D."
}

THE PREOPERATTVE SEDATTON of patients poses several unsettled problems to the anaesthetist. Their extent may best be judged by the continuing stream of communications concerning the use of new drugs as premedicating agents in spite of the great methodological difficulties associated with such studies.

Diazepam (Valium, Roche) has been extensively used in the last few years as a tranquillizer. Recent studies indicate that it possesses attractive qualities as a premedicating agent ${ }^{1,2}$ and that it causes little respiratory depression, ${ }^{3}$ usually the limiting factor in the dosage of sedative or narcotic drugs. With the preparation of a parenteral formula it appeared of interest to find out whether or not diazepam has appreciable advantages over meperidine, currently among the most popular premedicating drugs; all the more so since concern is growing about the effect of meperidine on respiratory homeostasis. ${ }^{4}$

\section{Material and Methods}

A determined effort was made to include all patients undergoing certain selected operations while this study was in progress. A separate batch of 2 c.c. ampouls was made up for each group of operations. Each batch contained an equal number of meperidine and diazepam ampouls bearing a code unknown to the investigators, and each ampoule contained meperidine $100 \mathrm{mg}$. or diazepam $10 \mathrm{mg}$., the equipotency of these amounts having been established previously. ${ }^{3}$ Patients weighing more than $150 \mathrm{lbs}$. were given the full dose, those weighing less than 100 lbs. received 1 c.c., while patients in between were given 0.2 c.c. additional for each $10 \mathrm{lbs}$. over $100 \mathrm{lbs}$.

The patients were seen during preanaesthetic rounds by one of the authors and their written consent to participate in the blind study was solicited. It was obtained in more than 85 per cent of all patients interviewed. A questionnaire was filled out at that time, and particular attention was paid to the patients' previous anaesthetic experience.

All premedication was administered at 0700 hours without regard to the scheduled time of operation. On the patients' arrival in the operating room they were again questioned, and further information was added to the sheet during anaesthesia and in the recovery room. The form was completed during postanaesthetic rounds on the day following surgery when the patients were again questioned in some detail.

-From the departments of Anaesthesiology and Obstetrics and Gynecology, Notre-Dame Hospital, Montreal. This study was supported by a grant from Dr. N. R. Kauf.nann of Hoffmann-La Roche Ltd., Montreal. Reprint requests should be directed to M. Keéri-Szántó, Dept. of Anaesthesiology, Notre-Dame Hospital, Montreal 24. 
In continuation of an earlier study, ${ }^{6}$ heparanized blood samples were drawn from the patients before induction and fifteen minutes after the first injection of thiopental. These were observed for the rate of RBC-sedimentation and were later analysed for total plasma proteins and plasma A/C ratio. Results of more detailed investigations of the plasma will follow.

The anaesthetic techniques in this series were rigidly standardized. For uterine dilatation and curettage, installation was completed and the surgeons were in the operating room, scrubbed and gowned, before anaesthesia was induced with thiopental $1 \mathrm{mg}$. per $\mathrm{lb}$. of body weight. Anaesthesia was maintained by $\mathrm{N}_{2} \mathrm{O} 5$ litres $+\mathrm{O}_{2} 2$ litres per minute in a semiclosed circuit with assisted ventilation. The depth of anaesthesia was adjusted with further increments of thiopental as required.

For laparotomies, anaesthesia was induced with thiopental $1 \mathrm{mg}$. per lb. Hyperventilation was started with halothane 1 per cent in $\mathrm{N}_{2} \mathrm{O} 5$ litres $+\mathrm{O}_{2} 2$ litres per minute, and the patient was intubated with the aid of suxamethonium $50 \mathrm{mg}$. Following intubation, the gas flow was reduced to halothane 1 per cent in $\mathrm{N}_{2} \mathrm{O} 2$ litres $+\mathrm{O}_{2} 1$ litre per minute, and the patients were attached to respirators which ventilated them at a rate of 12 to 15 per minute, with a tidal volume about 20 per cent greater than the value derived from the Radford nomogram.

Keeping in mind the results of earlier investigations of the effect of halothane concentrations greater than $I$ per cent upon liver function during and after laparotomies, ${ }^{6}$ we decided against exceeding this limit at any time. In only one patient out of one hundred did we get the impression that the anaesthesia was not deep enough-in this individual meperidine $30 \mathrm{mg}$. intravenously corrected the situation. The anaesthetists were of course free to reduce the halothane concentration in the anaesthetic circuit as they saw fit. The usual maintenance flow was around $20 \mathrm{ml}$. halothane vapour per minute. Satisfactory operating conditions were assured by increments of d-tubocurare, ranging from 3 to $12 \mathrm{mg}$.

The patients studied in this fashion underwent the following operations:

$\begin{array}{ll}\text { D \& C } & 60 \\ \text { Gastric surgery } & 20 \\ \text { Biliary surgery } & 40 \\ \text { Gynecologic laparotomies } & 40\end{array}$

Seven patients participated more than once in this study, either because their operations were first cancelled ( 1 patient) or because they were re-operated upon: these latter patients typically underwent $D$ \& $C$ followed by hysterectomy a few days later.

The statistical significance $(p)$ of our observations was determined by chisquare or $t$-tests as the case may be.

\section{Results}

Table I summarizes the physical characteristics of our patient population.

Table II concerns preoperative observations of the action of the premedicant drug.

Table III shows events during surgery, in the recovery room, and during the following 24 hours. 
TABLE I

Characteristics of the Patient Population

\begin{tabular}{lcr}
\hline & Diazepam & Meperidine \\
\hline Number of patients & 83 & 77 \\
Age (years $\pm \sigma)$ & $41.0 \pm 12$ & $42.6 \pm 15$ \\
Age, range & $19-69$ & $15-80$ \\
Weight (lbs. $\pm \sigma$ ) & $134 \pm 19$ & $131 \pm 32$ \\
Weight, range & $91-206$ & $85-245$ \\
Patients other than risk $\# 1$ & 11 & 14 \\
\hline
\end{tabular}

TABLE II

Observations before Surgery

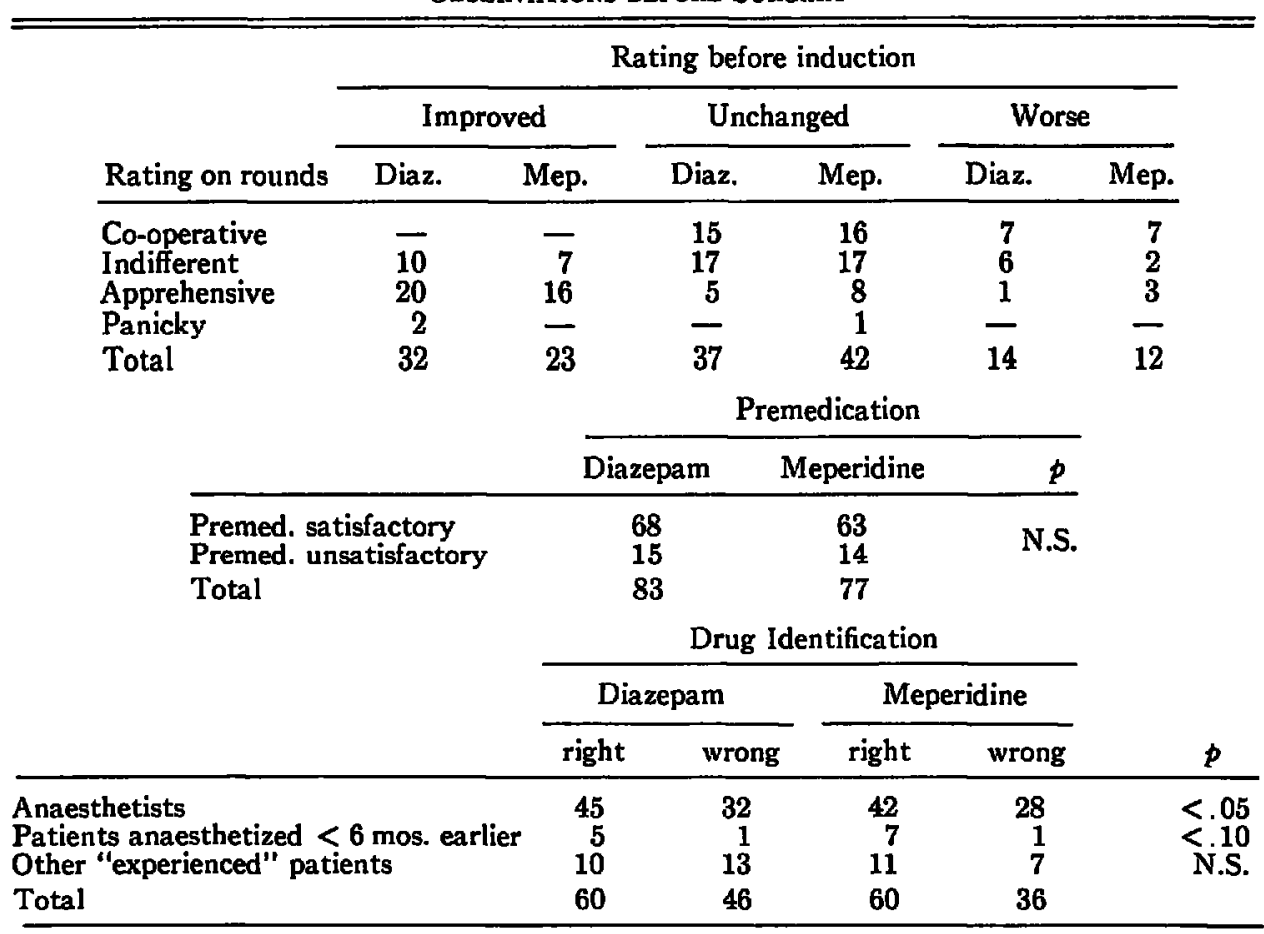

TABLE III

Observations during and after Surgery

\begin{tabular}{|c|c|c|}
\hline & $\begin{array}{l}\text { Diazepam } \\
\text { (arithmetic }\end{array}$ & $\begin{array}{l}\text { Meperidine } \\
\text { ( means) }\end{array}$ \\
\hline \multirow{6}{*}{$\begin{array}{l}\text { Minutes between premedication and } \\
\text { induction } \\
\text { Minutes anaesthesia time } \\
\text { Thiopenthal (mg./100 lbs./20 minutes, } \\
60 \mathrm{D} \& \mathrm{C} \text { patients only) } \\
\mathrm{D} \text {-tubocurare (mg./100 lbs./100 minutes, } \\
\text { 100 laparotomy patients only) } \\
\text { Show tongue, minutes after end of surgery } \\
\text { State time, minutes after end of surgery } \\
\text { Discharged from recovery room, minutes } \\
\text { after end of surgery } \\
\text { Ana lgesics, doses during first } 24 \text { hours after } \\
\text { end of surgery }\end{array}$} & $\begin{array}{l}181 \\
100\end{array}$ & $\begin{array}{r}208 \\
97\end{array}$ \\
\hline & & \\
\hline & 216 & 269 \\
\hline & $\begin{array}{r}13.9 \\
9.0 \\
29.6\end{array}$ & $\begin{array}{l}13.4 \\
10.2 \\
28.9\end{array}$ \\
\hline & 62.1 & 64.7 \\
\hline & & \\
\hline
\end{tabular}


Table IV presents information gleaned from our patients during postanaesthetic rounds.

Table V contains observations on blood samples drawn before surgery.

TABLE IV

Patients' Comments on the Premedication

\begin{tabular}{lcc}
\hline & Diazepam & Meperidine \\
\hline Premedication "too light" (patients) & 7 & 5 \\
Premedication "worn off" (patients) & 7 & 5 \\
Average time "worn oft" (hours) & 2.4 & 3.2 \\
Preanaesthetic nausea (patients) & 3 & 8 \\
Prefer this premedication (patients) & 12 & 5 \\
Note no difference (patients) & 7 & 9 \\
Prefer other premedication (patients) & 6 & 4 \\
Postanaesthetic nausea (patients) & 30 & 33 \\
More this time (patients) & 0 & 3 \\
Less this time (patients) & 3 & 1 \\
\hline
\end{tabular}

TABLE V

Observations on Blood Samples Drawn before Induction

\begin{tabular}{|c|c|c|c|c|c|c|}
\hline & \multicolumn{3}{|c|}{ Premedication } & \multicolumn{3}{|c|}{ Agent } \\
\hline & $\begin{array}{l}\text { Satis- } \\
\text { factory }\end{array}$ & $\begin{array}{l}\text { Unsatis- } \\
\text { factory }\end{array}$ & $p$ & Diazepam & Meperidine & $p$ \\
\hline $\begin{array}{l}\text { ESR (sedimentation) } \\
\text { Normal (patients) } \\
\text { Increased (patients) }\end{array}$ & $\begin{array}{l}52 \\
37\end{array}$ & $\begin{array}{r}16 \\
8\end{array}$ & N.S. & $\begin{array}{l}40 \\
15\end{array}$ & $\begin{array}{l}28 \\
30\end{array}$ & $<.02$ \\
\hline $\begin{array}{l}\text { Plasma protein } \\
<6.9 \mathrm{gm} \text {. per cent (patients) } \\
>6.9 \mathrm{gm} \text {. per cent (patients) }\end{array}$ & $\begin{array}{l}48 \\
72\end{array}$ & $\begin{array}{l}14 \\
15\end{array}$ & N.S. & $\begin{array}{l}28 \\
47\end{array}$ & $\begin{array}{l}24 \\
40\end{array}$ & N.S. \\
\hline $\begin{array}{l}\text { Plasma A/G ratio } \\
<1.10 \text { (patients) } \\
>1.10 \text { (patients) } \\
\end{array}$ & $\begin{array}{l}63 \\
57 \\
\end{array}$ & $\begin{array}{r}7 \\
22 \\
\end{array}$ & $<.001$ & $\begin{array}{l}36 \\
39 \\
\end{array}$ & $\begin{array}{l}34 \\
40 \\
\end{array}$ & N.S. \\
\hline
\end{tabular}

\section{COMMENT}

The data in Table I and parts of Tables II and III confirm that randomization has been successful. From the results of Table IV it appears that the two agents were employed in equipotent dosage. The formal criteria of a double blind study have been met, and the analysis of the results by statistical techniques, described above, is proper.

Premedication was considered unsatisfactory in close to 20 per cent of our patients with both agents. This was due to our strict criteria and to the limitations imposed by the nature of our study rather than to pharmacological properties of the drugs themselves. Most of the poorly premedicated patients could be readily identified during preanaesthetic rounds, and under different circumstances they would have received a larger dose or the combination of two sedatives. Interestingly, we noted no relationship between the success of premedication and the time elapsed between premedication and induction. This was anticipated for diazepam, but we did not expect meperidine to exert a sedative action as long as 
seven hours after the administration of moderate doses; yet in many instances this was the case. We were left with the clear impression that premedication of the entire operating list at 0700 hours is a practical procedure, provided that the patients are properly informed during preanaesthetic rounds, and that arrangements are made to give to the roughly ten per cent who need it a "topping off" dose before they are moved from their beds. The advantages of such a routine should be obvious: it provides sedation for the whole morning preceding surgery, and it does away with delays or with instances where patients receive their premedication only minutes before induction. If the routine is adopted, parasympatholytic drugs may be administered intravenously on the operating table as one sees fit.

The muscle relaxant properties claimed for diazepam ${ }^{7}$ did not result in any appreciable reduction of d-tubocurare requirements during surgery (Table III). Thiopental requirements remained the same in both groups. Recovery times, judged by three different criteria, and postoperative analgesic needs failed to differentiate between the two drugs. A statistically significant difference was observed, however, in the incidence of increased erythrocyte sedimentation rate (ESR), favouring diazepam (Table V). The interpretation of this finding awaits further study, as does the statistically highly significant correlation between clinically unsatisfactory premedication and elevated plasma $A / G$ ratio.

Experienced observers and previously anaesthetized patients correctly differentiated between drugs with significantly greater success than might have been expected from chance alone (Table II). This finding indicates nothing more than that these agents act differently. Which of the two has more desirable features as a premedicant may be seen from Tables II, IV, and V:

Meperidine was favoured over diazepam where the action of the premedication was "too light" or "too short." (As noted above, this objection could have been eliminated in most instances by more flexible dosage.) Diazepam was favoured over meperidine on the basis of reduced nausea before and after surgery, improvement in the patients' rating at induction, preference indicated by experienced subjects, and incidence of increased ESR before induction. While each of these parameters appears of considerable interest, the differences themselves are minimal in some instances and do not exceed 10 per cent statistical significance in the others, except for the ESR. They furnish no convincing proof that in the clinical situation outlined diazepam is superior to meperidine as a premedicant. They strongly suggest, however, that the two drugs are at least of comparable value and may be employed in the preparation of patients for surgery with much the same expectation of success.

\section{SUMMary}

The premedicant action of diazepam was compared with meperidine in a double-blind study involving 160 patients. Sixty patients underwent D \& C; the other 100 had laparotomies.

The results indicate that satisfactory premedication can be obtained in most patients by prescribing the drugs at 0700 hours regardless of the hour of surgery. 
The two compounds produced no statistically significant difference in any of the major parameters by which the success of premedication could be judged. What difference was observed, however, tended to favour diazepam.

\section{RÉSUMÉ}

Chez 160 patients (60 curettages utérins et 100 laparotomies), nous avons comparé, à double insu, les effets d'une médication pré-anesthésique au diazepam et à la mépéridine.

Les résultats obtenus avec l'un et l'autre de ces médicaments ont été, pour la plupart de ces patients, comparables et satisfaisants, selon les paramètres d'évaluation d'une médication pré-anesthésique. Cependant, quelques comparaisons sans signification statistique, semblent en faveur du diezepam.

Nous avons observé par ailleurs d'aussi bons effets de ces deux médications données à 7 A.M., quelle que fût l'heure de l'opération.

\section{ACKNOWLEDGMENTS}

The authors are indebted to the entire surgical and anaesthetic staff of the hospital who willingly put up with the delays and inconveniences that such investigations as this entail. Even greater thanks are due to our patients: without their informed consent and full co-operation much of the information presented here could not have been collected.

\section{REFERENCES}

1. Brandt, A. L. \& OAkes, F. D. Preanesthesia Medication: Double-Blind Study of a New Drug, Diazepam. Anesth. \& Analg. Curr. Res. 44: 125 (1965).

2. Tonnetra, F. J. Diazepam as Preanesthetic Medication: A Double-Blind Study. Anesth. \& Analg. Curr. Res. 44: 449 (1965).

3. Sadove, M. S.; Balacot, R. C.; \& McGratr, J. M. Effect of Chlordiazepoxide and Diazepam on the Influence of Meperidine on the Respiratory Response to Carbon Dioxide. J. New Drugs. 5: 121 (1965).

4. Pierce, J. A. \& Garofalo, M. L. Preoperative Medication and Blood Gases. J.A.M.A. 194: 487 (1965).

5. Krérar-Szántó, M. \& Labarke, J. Buthalitone Sodium Anesthesia: Drug-Consumption and Serum Protein Studies. Canad. Anaesth. Soc. J. 4 : 338 (1957).

6. Audet, J; Beaudonv, G.; Ké́ri-Szánto, M.; \& Trop, D. Halogenated Anesthetics and Innovar: A Comparative Liver Function Study. Third World Congress of Anes., São Paulo, Vol. II, 78-85 (1964).

7. Rogers, S. P. Clinical Observations of Diazepam a New Muscle Relaxant. Western Med. 4: 51 (1963). 